\title{
A Model of the Dynamic of the Relationship between Stock Prices and Economic Growth of Indonesia
}

\author{
Pasrun Adam ${ }^{1}$ \\ ${ }^{1}$ Department of Mathematics, Universitas Halu Oleo, Kendari, Indonesia \\ Correspondence: Pasrun Adam, Department of Mathematics, Universitas Halu Oleo, Kampus Bumi Tridharma \\ Anduonohu, Kendari 93232, Indonesia
}

Received: April 20, 2015

Accepted: May 5, 2015

Available online: May 20, 2015

doi:10.11114/aef.v2i3.829

URL: http://dx.doi.org/10.11114/aef.v2i3.829

\begin{abstract}
This study aimed to examine the dynamic of the relationship between stock prices and economic growth in Indonesia over the period from the first quarter 2004 to the fourth quarter 2013. The study analyzed two types of quarterly data, i.e., data about stock prices that referred to stock price index issued by Indonesian Stock Exchange and data of economic growth that referred to the percentage of changes in gross domestic product (GDP). To analyze the dynamic of the relationship, the general univariate causal model of LVAR was employed. Findings revealed that there was a significant dynamic of relationship between the two variables under investigation. The relationship was positive, meaning that when stock prices went up (went down), then the economic growth of Indonesia went up (went down) as well. Each $1 \%$ increase (decrease) in the stock prices was always followed by $0.09 \%$ increase (decrease) in Indonesian economic growth.
\end{abstract}

Keywords: stock prices, GDP, economic growth, LVAR

\section{JEL Classification: C22, E10, G10}

\section{Introduction}

Stock is one of instruments on financial market. When a company decides to finance itself, issuing shares is one of the choices it can make. In addition, stock is an instrument of investment that many investors choose to do. An investment offering a great deal of benefits has always attracted investors. If a stock investment is perceived to be profitable, many investors will buy the stock. If this happens, then the stock price will raise. On the other hand, if investors consider the stock less profitable, then they will have little or no intention to purchase the stock, in turn causing the stock price to decrease.

Changes in stock prices are also related to future economic activities. Many believe that a decrease in stock prices indicates future recession, whereas a large increase in stock prices will lead to economic growth in the future. For this reason, stock prices can be used as an predictor of the economy (Comincioli, 1995). When many investors predict an increase in the dividend in the future, then future economic activities are expected to flourish as well. In consequence, many investors will buy stocks, causing share prices to rise immediately (Croux and Reusens, 2013). Pearce (1983) argues that current increase in stock prices is an indication of future economic growth, since the rise of stock prices will push up domestic expenditure, which in turn can increase economic outputs.

The trends of stock prices and economic outputs in some countries in the past have received many attentions from economists and experts in finance, for example, Fama (1981) who conducted a study in the United States, Silverstovs et al. (2006) in Europe, and Gupta and Hartley (2013) in South Africa. Studies on the relationship between stock prices and economic growth have been conducted by, among others, Lee (1982), Hassapis and Kalyvitis (2002), Kim and In (2003), Duca (2007), Panopoulou (2009), Tsouma (2009). Ritter (2005), Cole et al. (2008), Zhou et al. (2012), and Chun et al. (2013). However, no agreement has been reached yet regarding the true relationship between stock prices or stock returns and economic growth. Some researchers, e.g. Ritter (2005), report that the relationship between stock prices or stock returns and economic growth is negative, occurring generally at company level (Chun et al., 2013). Other studies, e.g. by Fama (1981), Kim and In (2003), Beck and Levine (2004), Cole et al. (2008), and Zhou et al. (2012) to mention just a few, show a positive relationship between stock prices and economic growth. Others, suprisingly, conclude that in the long term there is no relationship between stock prices and economic growth (Sentruk 
et al, 2014). What make these studies come up with different results is possibly the economic condition of the country in which the research was carried out or by the period under investigation. For example, Sentruk et al (2014) did a research in Turkey and found that while there was no association between stock prices and economic growth in the long term, a correlation between the two variables existed in the short term. Furthermore, most of the studies were conducted in developed countries, e.g. Lee. B (1992), Levin and Zevros (1998), Chen et al. (1999), Hassapis and Kalyvitis (2002), Kim and In (2003), Binswanger (2004), and Duca (2007). Only few researchers, e.g. Mun et al. (2008), Ikoku (2010), Olweny and Kimani (2011), Babatunde (2013), and Sentruk et al. (2014), conducted their studies on developing countries.

Indonesia is a developing country and its stock market has been running and evolving since 1952. Indonesia Stock Exchange, a state-owned agency, manages the country's stock market. Since 1982, this agency has issued joint-stock index that serves as an indicator of stock market trend in Indonesia (Darmadji and Fakhruddin, 2012). If we consider historical data about the development of share prices between January 2004 and December 31, 2014, it is clear that while stock index fluctuated, it showed a rising trend from 735.68 in the first quarter 2004 to 4,291.88 in fourth quarter 2013. In the same period, Indonesian GDP indicated a positive trend, from USD 536,605.30 billion in the first quarter 2004 to USD 2,367,928.70 billion in the fourth quarter 2013.

This study aimed to investigate the dynamic of the long-term, one-way relationship between stock prices and Indonesian economic growth between the first quarter January 2004 and the fourth quarter December 2014, and establish a model of the relationship. To examine the relationship, the general univariate LVAR causal model proposed by Agung (2009) was empoyed. Analysis of the relationship was based on the assumption that the dynamic of the relationship between stock prices and economic growth does not occur instantly; rather it requires a certain time lag. Furthermore, test results were used to determine a model of the dynamic of the relationship between the two variables.

This paper is organized in five sections: section 1 is an introduction, section 2 gives a literature review, section 3 presents data and methodology, section 4 provides estimation results, and section 5 offers some conclusions.

\section{Review of Literature}

Theoretically, the relationship between stock prices $(p)$ and economic growth can be construed in the following model of the fundamental valuation of equity

$$
p_{t}=\sum_{j=1}^{\infty} \frac{E\left(D_{t+j}\right)}{(1+k)^{j}}
$$

where $E\left(D_{t+j}\right)$ refers to expected dividend at time $t+j$, and $k$ is discount rate ( $k$ is normally considered contant). Equation (1) shows that stock price is future benefit expected to be gained by stockholders from stock-issuing companies. This estimation is directly related to the real economic activities of a country. An economic recession usually refers to a situation when stock investment will result in smaller profits, and as a result, company that issues shares will provide lower dividend. If investors foresee that profits and dividends provided by the company will go down (up), then according to equation (1), stock prices will fall (rise). Equation (1) also demonstrates that the rise (fall) of discount rate will lead to a decrease (increase) in stock prices. Changes in stock prices or stock returns serve as a basis upon which real economic growth in the future can be predicted (Harvey, 1989). Thus, according to equation (1), stock prices are positively correlated with expected real activity.

Another theory, which holds that stock prices can predict future real economy, is the wealth effect. The theory postulates that if a stock price rises, investors will purchase shares in order to increase their wealth, causing expenditure to increase as well. In turn, this will cause economy to flourish. On the contrary, a fall in the stock price will cause investor's wealth gained from stock investments to go down as well, and this will reduce spendings, in turn causing to a decrease in economic growth (Foresti, 2006).

Mandelker and Tandon (1985) attempted to determine the relationship between common stock return, real activity, money, and inflation within the period 1966-1979 in USA, UK, France, Canada, Japan, and Belgium. Real activity was proxied to industrial production and gross national product (GNP). The researchers employed the linear regression to test the relationship. Results of their analysis showed (a) a negative relationship between stock returns and inflation, (b) a negative relationship between inflation and growth of real activity, and (c) a positive relationship between stock returns and growth of real activity (i.e. industrial production and real GNP)

Nadjand and Noronhand (1998) examined the relationship between inflation, stock returns, interest rates, and real activity in Japan over the period from January 1977 to December 1994. Data were analyzed by employing the ARIMA. Test results revealed the following relationships: stock returns were influenced by interest rates, whereas inflation was affected by economic growth, interest rates, and stock returns. Interest rates were affected by inflation and stock returns, 
thus interest rates and stock return have a two-way relationship. Economic growth was found to be affected by stock returns, and not the other way around.

A study by Choi et al. (1999) looked into the relationship between real stock returns and economic growth by using indicators of production index from January 1957 to March 1996 in all G7 countries (Canada, France, Germany, Italy, Japan, UK and USA). Using the VECM to test the relationship, the study found that, except in Italy, a correlation between stock prices and real economic growth occurred in all those countries. In the same period, Hassapis and Kalyvitis (2002) studied the relationship between changes in stock prices and real economic growth (growth of industrial production) from 1949 to 1998 in G7 countries. Results of the VAR test indicated a strong relationship between stock returns and economic growth. Binswanger (2004) also investigated the relationship between stock returns and growth of real activity from 1960 to 1999 in the seven G7 countries. Results of analysing quarterly data by using the VECM showed a strong correlation between stock returns and growth of GDP.

Mauro (2003) investigated the correlation between stock returns, real interest rates, money growth, and output growth in the period 1971-1998 in some emerging-market countries, including Argentina, Chili, Greece, India, Korea, Mexico, Thailand, and Zimbabwe), and in several developed countries (Australia, Austria, Belgium, Canada, Denmark, France, Germany, Italy, Japan, Netherlands, Norway, Singapore, Sweden, Switzerland, United Kingdom, USA, and Spain). Results of analysis, which employed the panel regressions, revealed that there was a correlation between stock returns and output growth not only in the emerging-market counties but also in the developed countries under investigation. It was further discovered that asset price is a strong predictor to output growth.

Siliverstovs and Duong (2006) looked into the relationship between stock market, economic activities represented by GDP, and interest rates in the period 1985Q1-2004Q4 in four European countries, including Germany, France, Italy, Netherlands, and UK. A statistical testing instrument used to determine the relationship between those variables was the VAR model. Results of examining quarterly data indicated a positive correlation between stock prices and GDP in those four countries. Furthermore, the share price was found to be a strong predictor to GDP.

Mun et al. (2008) examined the relationship between stock prices and economic growth in Malaysia from 1977 to 2006. The study empoyed the VAR and Granger causality to analyze data of stock index issued by Kuala Lumpur Composite Index, and the growth of GDP to measure economic growth. Results showed that there was a one-way relationship between the two variables, that is, stock index affected the economic growth of the country.

Enisan and and Olufisayo (2009) studied the long-term relationship between stock market and economic growth of Egypt and South Africa within the period 1980-2004. Using the causal models of autoregression-distributed lag (ARDL) to establish the relationship, the study found that stock market had a positive effect on the economic growth of Egypt and South Africa.

Budden et al. (2010) investigated the effect of stock prices, Brazilian currency exchange, inflation expectation, and deficit of government spending on the GDP of Brazil in the period 1996Q3-2009Q3. Employing the multiple regression analysis to examine the effect, the study reported that stock prices and deficit in government spending positively affected GDP rates. Meanwhile, inflation expectation had a negative effect on the GDP.

Ikoku (2010) conducted a study to examine the causal relationship between stock prices, GDP, and index of production in Nigeria in the period 1984Q1-2008Q4. Using quarterly data to test this relationship, result of a co-integration test indicated that stock prices and GDP were cointegrated. Further, results of testing the relationship by using the VECM model and Granger causality showed a causal relationship between stock prices and GDP. The study also found that share price is a predictor to GDP. Omowunmi and Oluseye (2011) investigated the effect of stock market on the economic growth of Nigeria in the period 1985-2009. Indicators of stock market included stock index and trading volume. They used multiple regression models to test the effect. Test results showed that stock market significantly affected economic growth. Taiwo et al. (2012) examined the effect of crude oil prices, stock prices, and two macroeconomic variables (i.e. interest rates and exchange rate) on Nigerian economic growth in 1980-2010. Result of testing the effect by using the causal model of Error Correction indicated that oil prices, stock prices, and exchange rates affected the economic growth of the country.

Olweny and Kimani (2011) studied the causal relationship between stock market performance and economic growth of Kenya in the period 2001-2010. The study analyzed quarterly data and employed the VAR model to examine this relationship, and the Granger causality test to determine the direction of the relationship. Results of analysis showed a one-way relationship between the two variables, i.e., economic growth affected price index. 


\section{Data and Methodology}

\subsection{Data}

The study examined data from the period 2004Q1-2013Q4. Two types of data were analyzed, i.e. quarterly data of stock prices and data of economic growth. Data about stock prices refered to the composite stock prices index (CSPI) issued by the Indonesia Stock Exchange and were retrieved from www.duniainvestasi.com. Data of this type is expressed by $s$.

Data of economic growth referred to changes in GDP and were obtained from the website of the Indonesian Central Statistics Agency (www.bps.go.id). This type of data is expressed by $g$. Data about economic growth at $t$ time is calculated by using the formula below

$$
g_{t}=\frac{G D P_{t}-G D P_{t-1}}{G D P_{t-1}} \times 100 \%
$$

in which $t$ refers to quarter unit.

\subsection{Methodology}

The underlying assumption of this study is that the dynamic of the relationship between stock price index and economic growth requires certain quarterly time lag $q \geq 0$. This is because the share price is a predictor for future economic activity (Comincioli, 1995; Stock and Watson, 2003; Croux and Reusens, 2013). In addition, government has always been making every effort to make the GDP of its country higher than it was in the previous years. Based on these assumptions, the econometric analysis instrument used was the general univariate causal model LVAR $(p, q)$ proposed by Agung (2009). The causal model of the dynamic of the relationship between stock price index $(s)$ and economic growth $(g)$ at $t$ time, is

$$
g_{t}=a_{0}+\sum_{i=1}^{p} a_{i} g_{t-i}+\sum_{j=0}^{q} b_{j} s_{(t-j)}+\epsilon_{t}
$$

where $a_{i}(i=1, \ldots, p), b_{j}(j=0,1, \ldots, q), p$ is regression parameter, $q$ is quarterly time lag, and $\epsilon_{t}$ is error term. Enders (2004) offers an alternative form to (2), as follows:

$$
g_{t}=a_{0}+\sum_{i=1}^{p} a_{i} g_{t-i}+x_{t}
$$

where $x_{t}$ can be one or several quarters of $\sum_{j=0}^{q} b_{j} s_{t-j}+\varepsilon_{t}$. The $x_{t}$ variable is called the forcing process (see Adam et al., 2015a; Adam et al., 2015b).

A coefficient of long-term response, also called the multiplier $(\lambda)$ of stock price index $(s)$ on economic growth $(g)$, is obtained when stock price index and economic growth are no longer changing, or the system is in an equilibrium state, thereby $g_{t}=g_{t-1}=g_{t-2}=\cdots=g_{t-p}$ and $s_{t}=s_{t-1}=s_{t-2}=\cdots=s_{t-q}$. Based on this condition, the multiplier of stock price index on the economic growth obtained from the causal model (2) is

$$
\lambda=\frac{\sum_{i=0}^{q} b_{i}}{1-\sum_{i=1}^{p} a_{i}}
$$

The value of $\lambda>0$ indicates a positive dynamic of relationship, whereas $\lambda<0$ shows a negative one (Heij et al., 2004). To examine the dynamic of the relationship, three stages of analysis are conducted.

Firstly, stationary test (or unit root test) is carried out. For this purpose, the Augmented Dickey-Fuller is used as a tool of analysis. By way of example, examining the stationarity of stock price index is carried out by determining the coefficient significance of $\rho$, using the following equation

$$
d\left(s_{t}\right)=\alpha+\beta t+\rho s_{t-1}+\sum_{i=1}^{n} \theta_{i} d\left(s_{t-i}\right)+\varepsilon_{t}
$$

and the following hypothesis

$$
\begin{aligned}
& H_{o}: \rho=0 \text {; the variable } s \text { is a nonstationary series } \\
& H_{1}: \rho \neq 0 \text {; the variable } s \text { is a stationary series }
\end{aligned}
$$

In equation (4) $\alpha, \theta_{i}(i=1,2, \ldots, n)$ are the regression parameter, $\varepsilon_{t}$ is error term, and $d\left(s_{t}\right)$ is the first difference variable of the stock price index of $d\left(s_{t}\right)=s_{t}-s_{t-1}$. The variable $s_{t}$ is stationary series, if the absolute value of ADF-statistic is greater than the absolute value of ADF-critic. In these tests, the significance level used is $1 \%$ or $5 \%$. The same way can also be applied to test the stationarity of the economic growth variable. The process of examining the 
stationarity begins at level $\left(s_{t}\right)$ and $\left(g_{t}\right)$, and if there is nothing stationary at level, then the process continues to test stationarity at first difference $\left(D\left(s_{t}\right)\right)$ and $\left(D\left(y_{t}\right)\right)$, and so on. If $s_{t}$ and $g_{t}$ are not stationary at level, but are stationary at first difference, then both variables $s_{t}$ and $g_{t}$ are said to be integrated of order one, $I(1)$ (Ariefianto, 2012).

Secondly, a cointegration test is conducted. This type of testing needs to be performed since the trend of both variables, i.e. stock price index and GDP, seems to move towards a common direction. The tool used to conduct the cointegration test is the Two Steps Engle-Granger cointegration. Following Noriega (2012), the first step is taken to estimate the regression between stock price index $\left(s_{t}\right)$ and economic growth $\left(g_{t}\right)$, on condition that each of the variables $s_{t}$ and $g_{t}$ are integrated of order one, $I(1)$. In this step, the error term in the regression equation is expressed by the variable Res, thus:

$$
\operatorname{Res}_{t}=g_{t}-\alpha-\beta s_{t}
$$

where $\alpha$ and $\beta$ are regression parameters. The second step is executed to test the stationarity of the Res variable. If Res is not stationary, then the trends of stock price index and economic growth are said to be not cointegrated. If this happens, and both variables are stationary at first difference, then the model of the dynamic of the relationship between stock price index and economic growth (without trend) (Koop, 2006) is as follows

$$
D\left(g_{t}\right)=a_{0}+\sum_{i=1}^{p} a_{i} D\left(g_{t-i}\right)+\sum_{j=0}^{q} b_{j} D\left(s_{(t-j)}\right)+\epsilon_{t}
$$

If stock price index and economic growth are cointegrated, and both variables are not stationary at level but are stationary at first difference, then the model (5) becomes

$$
D\left(g_{t}\right)=a_{0}+\delta \operatorname{Res}_{t-1}+\sum_{i=1}^{p} a_{i} D\left(g_{t-i}\right)+\sum_{j=0}^{q} b_{j} D\left(s_{(t-j)}\right)+\epsilon_{t}
$$

where $\delta$ is the parameter. Model (6) is now called as the Error Correction Model (ECM) of the dynamic of the relationship between stock price index and economic growth.

Thirdly, a relationship test is carried out. This is done by examining the significance of the regression parameters, particularly parameter $b_{j}(j=0,1, \ldots, q)$ of the causal model (2), with the following formulated hypotheses

$$
\begin{aligned}
& H_{o}: \quad \text { all } \quad b_{j}=0, j=0,1, \ldots, q \text { (there is no relationship) } \\
& H_{1}: \quad \text { at least there is one } b_{j} \neq 0, j=0,1, \ldots, q \quad \text { (there is a relationship) }
\end{aligned}
$$

These hypotheses are tested by using a combination of the $p$-value rule of $F$-statistics on all parameters in the regression model (2), (5) or (6) and the $p$-value rule of $t$-statistics on each parameter regression model (2), (5) or (6). The testing criteria is that a regression parameter is said to be significant if the $p$-value of t-statistic (or the $p$-value of $F$-statistics) is smaller than the critical $p$-value at $1 \%$ or $5 \%$ level of significance. Hypothesis testing is conducted in a two-stage estimation, namely (a) estimating model (2), (5) or (6) in such a way that there is at least one coefficient of the stock price index variable $(s)$ is significant according to the criteria of the $p$-value of $t$-statistic, and also all the parameters are significant according to the criteria of the $p$-value of $F$-statistic; and (b) re-estimating the models, which is done only to variables obtaining significant coefficients in the previous stage. In drawing conclusion from this test, it is necessary to consider the optimum time lag in accordance to some criteria set by Akaike Information Criterium (AIC). In addition, testing decision should still consider the comparison between the statistical value of Durbin Watson $(D W)$ and the coefficient of determination $R^{2}\left(R^{2}<D W\right)$, in order to ensure that the estimation model is not a spurious regression.

\section{Estimation Result}

\subsection{Stationary Test (or unit root test)}

Table 1 presents the results of stationary test obtained from equation (4) both at level and first difference. As can be seen, the variable of stock price index is not stationary at level since the absolute value of ADF-statistic (2.43406) is smaller that the absolute value of ADF-critic at 1\% (3.592462). The variable of economic growth is also not stationary at level because the absolute value of ADF-statistic (2.009896) is smaller than that of the ADF-critic at 1\% (3.639407). Stock price index is stationary at first difference $D\left(s_{t}\right)$, since the absolute value of ADF-statistic (5.415500) is greater than that of the ADF-critic at $1 \%$ (3.596616). Likewise, the variable of crude oil prices is stationary at first difference $D\left(g_{t}\right)$ since the absolute value of ADF-statistic (4.353871) is greater than that of the ADF-critic at 1\% (3.639407). 
Table 1. Estimation results of ADF-statistic

\begin{tabular}{lccc}
\hline Variable & ADF-statistic & ADF-critic (1\%) & ADF-critic (5\%) \\
\hline$s_{t}$ & -0.243406 & -3.592462 & -2.931404 \\
$g_{t}$ & -2.009896 & -3.639407 & -2.951125 \\
$D\left(s_{t}\right)$ & -5.415500 & -3.596616 & -2.933158 \\
$D\left(g_{t}\right)$ & -4.353871 & -3.639407 & -2.951125 \\
\hline
\end{tabular}

4.2 Cointegration Test

Since both variables, i.e. stock price index and economic growth, are not stationary at level but are stationary at first difference, then a test is conducted to determine the cointegration between the trend of stock price index and the trend of economic growth. Employing the Two-Step Engle-Granger cointegration test, results show that the value of ADF-statistic is -3.334918 and the value of ADF-critic at $1 \%$ level of significance is -3.639407. By comparing these two ADF values, it is clear the Res error variable is not stationary at $1 \%$. In other words, the trends of both stock price index and economic growth are not cointegrated.

\subsection{Relationship Test}

Given the results of the cointegration test, estimation test on the dynamic of the relationship should not include the Res error correction variable. Thus, to estimate a model of the dynamic of the relationship between stock price index and economic growth, model (5) is employed. Results of this estimation are shown in Table 2.

Table 2. Results of the statistical estimation test on the relationship between stock price index and economic growth

\begin{tabular}{lccc}
\hline Variable & Coefficient & t-statistic & Prob. \\
\hline$D\left(g_{t-1}\right)$ & -0.864945 & -7.823757 & 0.0000 \\
$D\left(g_{t-2}\right)$ & -0.819621 & -7.016691 & 0.0000 \\
$D\left(g_{t-3}\right)$ & -0.803904 & -7.391319 & 0.0000 \\
$D\left(s_{t-2}\right)$ & 0.003083 & 2.440994 & 0.0206 \\
\hline R-squared & 0.737949 & Akaike info criterion & 4.438018 \\
Durbin-Watson stat & 1.967405 & Schwarz criterion & 4.615772
\end{tabular}

It is obvious from Table 2 that the coefficient of stock price index $D\left(s_{t-2}\right) 0.003083$ has the p-value 0.0206 that is less than 5\%, and this means that it is significant. Thus, a dynamic relationship between stock price index and economic growth existed. The dynamic of this relationship began to occur in the second quarter, as indicated by a time lag of the stock price index $q=2$. The dynamic of the relationship is also strengthened by $D W$ value (1.967405), which is greater than the value of determination $R^{2}=0.737949$. The model of the dynamic of the relationship between stock price index and economic growth is therefore as follows

$$
D\left(g_{t}\right)=-0.864945 D\left(g_{t-1}\right)-0.819621 D\left(g_{t-2}\right)-0.803904 D\left(g_{t-3}\right)+0.003083 D\left(s_{t-2}\right)
$$

Furthermore, the multiplier of the stock price index on economic growth is $\lambda=0.000884$. The positive sign in the value of this multiplier indicates that the dynamic of the relationship between the two variables is positive. This suggests that from the second quarter a rise (fall) of stock price index was always followed by an increase (decrease) in economic growth. Any increase (decrease) in stock price index by $1 \%$ was followed by the rise (fall) of economic growth by $0.09 \%$.

\section{Conclusion}

This study attempted to examine the dynamic of the relationship between stock prices and economic growth in Indonesia over the period 2004Q1-2013Q4. The Indonesian stock market referred to the composite stock price index (CSPI), whereas economic growth was represented by the percentage changes in GDP. To examine both variables, quarterly data were analyed. Testing of the dynamics of the relationship was conducted by using the LVAR model.

Results of estimation showed that the two variables, i.e. the stock price index and economic growth, were not stationary at level. They were, however, stationary at first difference. The trend of both variables was therefore not cointegrated.

Test results indicated that there was a significantly dynamic relationship between stock price index and economic growth. The dynamics of the relationship occured at the start of second quarter. The dynamic of this relationship was positive, meaning that when the stock price index rose (fell), then the economic growth of Indonesia also rose (fell). When the stock price increased (decreased) by $1 \%$, then at the start of time lag $q=2$ quarter the economic growth in the country rose (fell) by $0.09 \%$. 


\section{References}

Adam, P., Rianse, U., Cahyono, E \& Rahim, M. (2015a), Modeling of the dynamics relationship between world crude oil prices and the stock market in Indonesia. International Journal of Energy Economics and Policy, 5(2), $550-557$.

Adam, P., Rianse, U., Cahyono, E., Rahim, M., Syarief, \& Gamsir. (2015b), Modelling of the dynamics of the relationship between world crude oil price and Indonesia's trade balance: An LVAR analysis. Journal of Economics and Sustainable Development, 6(4), 156-161

Agung, I. G. N. (2009), Time series data analysis using Eviews. Singapore: John Wiley \& Son

Ariefianto, M. D. (2012). Ekonometrika esensi dan aplikasi dengan menggunakan Eviews. Jakarta: Penerbit Erlangga

Babatunde, O. G. (2013), Stock market volatility and economic growth in Nigeria (1980-2010). International Review of Management and Business Research, 2(1), 201-209

Binswanger, M. (2004), Stock returns and real activity in the G-7 countries: Did the relationship change during the 1980s? The Quarterly Review of Economics and Finance, 44, 237-252. http://dx.doi.org/10.1016/j.qref.2003.07.001

Beck, T., \& Levine, R. (2004), Stock markets, banks, and growth: Panel evidence. Journal of Banking \& Finance, 28, 423-442. http://dx.doi.org/10.1016/S0378-4266(02)00408-9

Budden, M. C., Cope III, R. F., Hsing, Y., \& Zee, S. M. L. (2010), Stock market performance, the exchange rate, and the Brazilian economy. Research in Applied Economics, 2(2), 1-10

Choi, J., Hauser, S., \& Kopecky, K., (1999), Does the stock market predict real activity? Time series evidence from the G-7 countries. Journal of Banking and Financ, 23(12), 1771-1792. http://dx.doi.org/10.1016/S0378-4266(99)00020-5

Cole, R., Moshirian, F., \& Wu, Q. (2008), Bank stock returns and economic growth. Journal of Banking \& Finance, 32 , 995-1007. http;//dx.doi.org/10.1016/j.jbankfin.207.07.006

Comincioli, B. (1995). The stock market as a leading economic indicator: An application of Granger causality. Digital Commons @IWU, Economics Department of Illinois Wesleyan University, available online http://digitalcommons.iwu.edu/

Croux, C., \& Reucens, P. (2013), Does stock prices contain predictive power for the future economic activity? A Granger causality analysis in the frekuency domain. Journal of Macroeconomics, 35, 93-103. http://dx.doi.org/10.1016/j.jmacro.2012.10.001

Chun, H. Kim, J-W \& Morck, R. (2013), Produktivity growth and stock return: Firm and aggregate-level analysis. NBER Working Paper, 19462, available online http://www.nber.org/papers/w19462

Duca, G. (2007), The relationship between the stock market and the economy: Experience from international financial markets. Bank of Valletta Review, 36, 1-12, available online https://www.bov.com/pjazza/bov-review---past-editions

Darmadji, T., \& Fakhruddin, H. M. (2012), Pasar modal Indoesia pendekatan tanya jawab (Edisi ke tiga). Jakarta: Penerbit Salemba Empat

Enders, E. (2004). Applied econometric time series. New York: John Wiley \& Son, Inc

Enisan, A., \& Olufisayo. (2009), Stock market development and economic growth: Evidence from seven sub-Sahara African countries. Journal of Economics and Business, 61, 162-171. http://dx.doi.org/10.1016/j.jeconbus.2008.05.001

Fama, E. F. (1981). Stock returns, real activity, inflation and money. American Economic Review, 71(4), 545-565.

Foresti, P. (2006). Testing for Granger causality between stock prices and economic growth. Munich Personal RePec Archive (MPRA), 62, available online http://mpra.ub.uni-muenchen.de/2962

Gupta, R \& Hartley, F. (2013), The role of asset price forcasting inflation and ouput in South Africa. Journal of Emerging Market Finance, 12(3), 239-291. http://dx.doi.org/10.1177/0972652713512913

Harvey, C. R. (1989). Forecasts of economic growth from the bond and stock markets. Financial Analysts Journal, 45(5), 38-45

Hassapis, C \& Kalyvitis, S. (2002). Investigating the link between growth and real stock prices changes with empirical evidence from the G-7 economies. The Quarterly Review of Economics and Finance, 42, 543-575. http://dx.doi.org/10.1016/S1062-9769(01)00111-9 
Heij, C., Paul de Boer., Frances, P. H., Kloek, T., \& Van Dijk, H. K. (2004). Econometric methods with application in business and economics. Clareendon : Oxford University Press

Ikoku, A. E. (2010). Is the stock market a leding indicator of economic activity in Nigeria?. CBN Journal of Applied Statistics, 1(1), 17-38, available online www.cbank.org/documents/cbnjas.asp

Kim, S., \& In, F., (2003). The relationship between financial variables and real economic activity: evidence from spectral and wavelet analyses. Studies in Nonlinear Dynamics and Econometrics, 7(4), 1-16. http://dx.doi.org/ 10.2202/1558-3708.1183

Koop, G. (2006). Analysis of financial data. New York : Wiley \& Son

Lee, B-S. (1992). Causal relations among stock returns, interest rates, real activity, and inflation. The Journal of Finance, 47(4), 1591-1603. http://dx.doi.org/10.1111/j.1540-6261.1992.tb04673.x

Levine, R., \& Zervos, S. (1998). What we have learnt about policy and growth from cross-country regressions. American Economic Review, 83(2), 426-440

Mauro, P. (2003). Stock returns and output growth in emerging and advanced economies. Journal of Development Economics, 71, 129-153. http://dx.doi.org/10.1016/S0304-3878(02)00136-0

Mendelker, G., \& Tandon, K. (1985). Common stock returns, real activity, money, and inflation: some international evidence. Journal of International Money and Finance, 4, 267-286. http://dx.doi.org/10.1016/0261-5606(85)90048-8

Mun, H. W., Siong, E. C., \& Thing T. C. (2008). Stock market and economic growth in Malaysia: Causality test. Asian Social Science, 4(4), 86-92

Najand, M., \& Noronha, G. (1998). Causal relations among stock return, inflation, real activity, and interest rates: evidence from Japan. Global Finance Journal, 9(1), 71-80. http://dx.doi.org/ 10.1016/S1044-0283(98)90015-1

Noriega, A. E., \& Ventosa-Santaularia, D. (2012). The effect of structural breaks on the Engle-Granger test for cointegration. Estudio Economicos, 27(1), 99-132

Olweny, T. O., \& Kimani, D. (2011). Stock market performance and economic growth empirical evidence from Kenya using causality test approach. Advances in Management and Applied Economics, 1(3), 153-196

Omowunmi, O. F., \& Oluseye, O. O. (2011). An empirical analysis of the effect of stock market crisis on economic growth: The Nigerian case. Acta Universitatis Danubius, 7(4), 172-186

Panopoulou, E. (2009). Financial variables and euro area growth: a non-parametric causality analysis. Economic Modelling, 26(6), 1414-1419. http://dx.doi.org/10.1016/j.econmod.2009.07.013

Pearce, D. K. (1983). Stock prices and the economy. Economic Review, Federal Reserve Bank of Kansas City, available online http://www.kansascityfed.org/PUBLICAT/ECONREV/EconRevArchive/1983

Ritter, J. R. (2005). Economic growth and equity returns. Pacific-Basin Finance Journal, 13, $489-503$. http;//dx.doi.org/10.1016/j.jpacfin.2005.07.001

Senturk, M., Oska, G. S., \& Akbas, Y. E. (2014). The relationship between economic growth and stock return: an example from Turkey. Doğuş Üniversitesi Dergisi, 15(2), 155-164

Siliverstovs, B., \& Duong, M. H. (2006). On the role of stock market for real economic activity: Evidence for Europe. DIW Berlin Discution Papers, 599, available online www.div.de

Stock, J. H., \& Watson, M. W. (2003). Forcasting output and inflation: The role of asset prices. Journal of Economic Literatur, 41(3), 788-829

Taiwo, M, Abayomi, T., \& Damilare, O. (2012). Crude oil price, stock price and some selected macroeconomic indicators: Implications on the growth of Nigeria economy. Research Journal of Finance and Accounting, 3(2), $42-48$

Tsouma, E. (2009). Stock returns and economic activity in mature and emerging markets. The Quarterly Review of Economics and Finance, 49(2), 668-685. http://dx.doi.org/10.1016/j.qref.2008.02.002

Zhou, C, Wu, C., Li, D., \& Chen, Z. (2012). Insurance stock return and economic growth The Genewa. Papers On Risk and Insurance-Issue Practice, 37, 405-428. http://dx.doi.org/:10.1057/gpp.2012.22

\section{(cc) $\mathrm{Br}$}

This work is licensed under a Creative Commons Attribution 3.0 License. 